\title{
The influence of storage time on relevant product properties of rubber seeds, rubber seed oil and rubber seed oil ethyl esters
}

\author{
Muhammad Yusuf Abduh ${ }^{1,2}$, Robert Manurung ${ }^{2}$ and Hero Jan Heeres ${ }^{1 *}$
}

\begin{abstract}
Background: Rubber seed oil (RSO) derived from rubber seeds is considered a promising plant oil. However, subsequent biodiesel synthesis from RSO was reported to be difficult due to the high acidity of the oil. Detailed studies on the effects of storage time of rubber seeds on relevant product properties such as acid value are not yet available. The authors here report a study on the influence of storage time on the moisture content of rubber seeds and the acid value of the oil within the seeds. In addition, the acidity of isolated rubber seed oil and the acidity of rubber seed oil ethyl esters versus time was determined.

Results: The moisture content as a function of the time for two different batches of rubber seeds, one with an initial water content of $3.1 \mathrm{wt} \%$ (obtained by drying the seeds at $60^{\circ} \mathrm{C}$ for 3 days) and another with a moisture content $10.7 \mathrm{wt} \%$ (as received, non-dried) were determined at $27^{\circ} \mathrm{C}$ and a relative humidity of $67 \%$ for a period of 2 months. The moisture versus time curves were successfully modelled using an analytical solution of the instationary diffusion equation and allowed determination of the diffusion coefficient of water in the rubber seeds at $27^{\circ} \mathrm{C}$. The acid value of the isolated rubber seed oil increased considerably in time for both cases (from 0.84 to $4.19 \mathrm{mg} \mathrm{KOH} / \mathrm{g}$ for the nondried seeds and from 0.51 to $2.13 \mathrm{mg} \mathrm{KOH} / \mathrm{g}$ for the dried seeds). Freshly isolated rubber seed oil and rubber seed ethyl esters derived thereof prepared using a transesterification reaction have a relatively low acid value of 0.52 and $0.32 \mathrm{mg} \mathrm{KOH} / \mathrm{g}$ respectively. The acid value of rubber seed oil only slightly increased during storage $(0.52-0.60 \mathrm{mg}$ $\mathrm{KOH} / \mathrm{g}$ ), whereas the acid value of the rubber seed ethyl esters $(0.32-0.33 \mathrm{mg} \mathrm{KOH} / \mathrm{g})$ does not change significantly.

Conclusions: Long-term seed storage led to an increase in the acid value of the oils present in the rubber seeds. Pretreatment (e.g. drying) of the rubber seeds showed a positive effect and the increase in acid value in time was lower than for the non-pretreated seeds. It is recommended to store the isolated rubber seed oil instead of the rubber seeds to minimize acid formation.
\end{abstract}

Keywords: Rubber seed, Rubber seed oil, Rubber seed ethyl ester, Storage, Acid value

\section{Background}

Biodiesel is an important renewable transportation fuel produced from triglycerides like virgin plant oils and waste cooking oils [1-3]. It is commercially available and widely used in many countries such as the US, Indonesia, Brazil, Germany and other European countries. Global biodiesel production grew at an average annual

\footnotetext{
*Correspondence: h.j.heeres@rug.nl

1 Department of Chemical Engineering, ENTEG, University of Groningen,

Nijenborgh 4, 9747 AG Groningen, The Netherlands

Full list of author information is available at the end of the article
}

rate of $17 \%$ from 2007 to 2012 [4]. In the US, the biodiesel industry recorded a total volume of nearly 5.67 million tonne in 2013, which exceeds the 2.52 million tonne/annum target set by the EPA's Renewable Fuel Standard [5]. The production of biodiesel in Europe has also increased dramatically in the period 2000-2011 and accounts for $41 \%$ of the global biodiesel output [4]. This increase is driven by the EU objective of a $10 \%$ biofuel share in the transportation sector by 2020 [6].

A wide range of oil-bearing crops have been identified as potential sources for the production of biodiesel. 
Edible oils such as rapeseed, sunflower oil, palm oil and soybean oil account for more than $95 \%$ of the current feeds used for biodiesel production [2]. However, there are many concerns regarding the use of such plant oils for non-food applications like biodiesel production and this stimulated the search for alternative feeds for the biodiesel industry.

A possible solution is the use of non-edible oils with a high oil content and productivity. Various studies have been performed to investigate the potential of non-edible oils such as jatropha, karanja and rubber seed oil [7-9] as the feedstock to produce biodiesel. Rubber seed oil (RSO), derived from rubber seeds, is considered a promising source because the seeds are reported to contain a high amount of oil (approximately 40-50\%) $[10,11]$ and are currently regarded as a waste. The productivity of rubber seeds is reported to be in the range of $100-$ $1200 \mathrm{~kg} / \mathrm{ha} / \mathrm{yr}[12,13]$. From a biorefinery perspective, the valorization of rubber seeds by biodiesel production is highly relevant as it increases the economic attractiveness of the rubber plantations.

The conversion of RSO into biodiesel has been reported in the literature $[10,14]$. However, the reported high acid value of RSO renders the conversion into biodiesel difficult [10]. Typically, an acid value of $4 \mathrm{mg} \mathrm{KOH} / \mathrm{g}$ is set as the maximum for plant oils whereas acid value for RSO between 2 and $81.6 \mathrm{mg} \mathrm{KOH} / \mathrm{g}$ have been reported [15]. These high free fatty acid (FFA) values are not necessarily an intrinsic feature of the RSO, but will be a function of the processing conditions and technology, as well as the storage conditions of the seeds [15].

Literature data on the effect of seed storage on the quality of RSO are scarce and only one study is available [15] (Table 1). In this study, rubber seeds were stored at two different storage conditions viz (i) in a controlled laboratory setting (entry 1 in Table 1 ) and (ii) in a traditional storehouse (entry 2 in Table 1). The acid value of isolated
RSO for entry 1 increased from 2 to $8.6 \mathrm{mg} \mathrm{KOH} / \mathrm{g}$, whereas a higher difference was found for condition 2 (from 2 to $30.8 \mathrm{mg} \mathrm{KOH} / \mathrm{g}$ ). In the same report, the effect of storage on the acid value of crude RSO was provided [15]. After 2 months at $27{ }^{\circ} \mathrm{C}$, the acid value increased from 18.1 to $31 \mathrm{mg} \mathrm{KOH} / \mathrm{g}$ (Table 1 ).

Studies on the influence of storage on relevant product properties of RSO ethyl esters are not available in the open literature. As such, the degradation of rapeseed oil methyl esters under different storage conditions was used as the benchmark [16]. Here, the acid value increased slightly from 0.15 to 0.22 after 1 year of storage at $4{ }^{\circ} \mathrm{C}$ (refer to Table 1 for storage conditions). Higher storage temperatures (from 4 to $40{ }^{\circ} \mathrm{C}$ ) led to an increase in the acid value from 0.22 to $0.75 \mathrm{mg} \mathrm{KOH} / \mathrm{g}$.

Therefore, we can conclude that detailed studies on the effect of storage time of rubber seed on relevant properties are not available yet. In addition, the one step trans-esterification of RSO with ethanol has never been reported before. We here report the influence of storage time on (i) the moisture content of rubber seeds and the acid value of the oil within the seeds, (ii) the acidity of isolated RSO and (iii) the acidity of RSO ethyl esters prepared from RSO. For rubber seeds, the effect of storage conditions on the moisture content of two different rubber seed fractions, one with an initial moisture content of $10.7 \mathrm{wt} \%$ and another with a moisture content of $3.1 \mathrm{wt} \%$, were determined and modeled. The latter allowed estimation of the diffusion coefficient of water in the rubber seeds at $27{ }^{\circ} \mathrm{C}$, which has not yet been reported in the literature. In addition, the effect of storage on the acid content of the oil in the rubber seeds, isolated RSO and RSO ethyl esters was investigated $\left(27^{\circ} \mathrm{C}\right.$, closed vessels). For this purpose, RSO ethyl esters were synthesized and relevant product properties after synthesis were determined, which is an absolute novelty of this paper.

Table 1 Overview of studies on the influence of storage conditions on the acid value of rubber seeds, rubber seed oil and rapeseed methyl esters

\begin{tabular}{|c|c|c|c|c|c|}
\hline \multirow[t]{2}{*}{ Entry } & \multirow[t]{2}{*}{ Material } & \multirow[t]{2}{*}{ Storage conditions } & \multicolumn{2}{|c|}{ Acid value $(\mathrm{mg} \mathrm{KOH} / \mathrm{g})$} & \multirow[t]{2}{*}{ Ref. } \\
\hline & & & Initial & Final & \\
\hline 1 & Rubber seed & Seeds stored in open crates $\left(27^{\circ} \mathrm{C}, 51 \% \mathrm{RH}\right)^{\mathrm{a}}$ & 2 & $8.6^{b}$ & [15] \\
\hline 2 & Rubber seed & Seeds stored large store rooms $\left(27^{\circ} \mathrm{C}, 51 \% \mathrm{RH}\right)^{\mathrm{a}}$ & 2 & $30.8^{\mathrm{b}}$ & [15] \\
\hline 3 & RSO & Stored in a closed container $\left(27^{\circ} \mathrm{C}, 51 \% \mathrm{RH}\right)^{\mathrm{a}}$ & 18.1 & $31^{\mathrm{b}}$ & [15] \\
\hline 4 & Rapeseed methyl ester & Stored in a closed container $\left(4^{\circ} \mathrm{C}\right)$ & 0.15 & $0.22^{c}$ & [16] \\
\hline 5 & Rapeseed methyl ester & Stored in a closed container $\left(20^{\circ} \mathrm{C}\right)$ & 0.15 & $0.28^{c}$ & [16] \\
\hline 6 & Rapeseed methyl ester & Stored in a closed container $\left(40^{\circ} \mathrm{C}\right)$ & 0.15 & $0.75^{c}$ & [16] \\
\hline
\end{tabular}

\footnotetext{
${ }^{a}$ Estimated room temperature and relative humidity (RH)

${ }^{\text {b }}$ After 2 months storage

c After 12 months storage
} 


\section{Methods}

Materials

Seeds from the rubber tree (Hevea brasiliensis) were obtained from Bengkulu, Indonesia. The mature fruits were harvested in September 2012. The seeds were dried in open air in the sun for 1 week before stored in crates $\left(27^{\circ} \mathrm{C}\right)$ and shipped to Institut Teknologi Bandung (ITB), Indonesia. The received seeds were stored at room temperature $\left(27^{\circ} \mathrm{C}\right)$ before experiments were carried out at ITB. The moisture content of the rubber seeds upon receipt was $11 \mathrm{wt} \%$, wet based (w.b.) whereas the moisture content of the dehulled rubber seeds (kernels) was $8 \mathrm{wt} \%$, w.b. Ethanol (absolute, pro analysis) and n-hexane (99\%, for analysis) was obtained from Emsure. Sodium ethoxide solution (21\% wt\%) in ethanol and $\mathrm{CDCl}_{3}(99.8 \%)$ were obtained from Sigma-Aldrich.

\section{Storage conditions}

The rubber seeds $(20 \mathrm{~kg})$ were split in two fractions of $10 \mathrm{~kg}$. One of the fractions was exposed to a pretreatment procedure, consisting of drying the seeds for 3 days in an oven at $60{ }^{\circ} \mathrm{C}$ (pretreatment, PT). The other fraction was used as such (no pretreatment, NPT). Both fractions were stored in a crate $(50 \times 30 \times 18 \mathrm{~cm})$ at $27^{\circ} \mathrm{C}$, see Table 2 for details. The humidity and temperature of the storage room were measured periodically during the 60 day storage time.

In addition, the moisture and oil content of the seeds and the acid value of the isolated RSO samples were periodically monitored for a 2 month period. RSO and RSO ethyl esters were stored in closed $20 \mathrm{~mL}$ glass bottles at $27{ }^{\circ} \mathrm{C}$. The acid values were periodically determined for a 2 month period. An overview of the storage conditions and measured variables are given in Table 2 .

Determination of the moisture content of the rubber seeds The total moisture content of the rubber seeds was determined using Method B-1 4 of the German Standard Methods (DGF, 2002). It involves heating the dehulled rubber seeds in the oven at $103^{\circ} \mathrm{C}$ until constant weight.

\section{Determination of the oil content of the rubber seeds}

The oil content of the rubber seeds were determined using a Soxhlet extraction, based on method B-1 5 of the
German standard methods (DGF, 2002). The seeds were dehulled and dried overnight at $103{ }^{\circ} \mathrm{C}$ before analysis. The dried kernels were ground using a coffee grinder. Approximately $5 \mathrm{~g}$ of sample was weighed with an accuracy of $0.0001 \mathrm{~g}$ and transferred to a Soxhlet thimble, covered with cotton wool and extracted with n-hexane for at least $6 \mathrm{~h}$. The solvent was evaporated in a rotary evaporator (atmospheric pressure, $69{ }^{\circ} \mathrm{C}$ ) and the samples were subsequently dried in an oven at $103{ }^{\circ} \mathrm{C}$ until constant weight. The oil content is reported as gram oil per gram sample on a dry basis.

\section{Hydraulic pressing of RSO}

A laboratory-scale hydraulic press was used to expel the oil from the rubber seeds. A detailed description of the hydraulic press is described elsewhere [17]. Prior to expression, the seeds were dehulled and dried in an oven at $60{ }^{\circ} \mathrm{C}$ for 3 days. Approximately $7 \mathrm{~g}$ of dried kernel (dehulled rubber seeds) was placed in the pressing chamber and pressed at $27{ }^{\circ} \mathrm{C}$ and $20 \mathrm{MPa}$ for $10 \mathrm{~min}$. The isolated RSO was stored at $27^{\circ} \mathrm{C}$ and the acid value was determined using an acid-base titration.

\section{Synthesis of RSO ethyl ester}

RSO ethyl ester were synthesised in a glass batch reactor $(20 \mathrm{~mL})$ immersed in a water bath. The reactor was filled with RSO (5 mL), ethanol (1.2 g, 6:1 molar ratio of ethanol to oil) and the sodium ethoxide solution ( $0.2 \mathrm{~g}, 1 \mathrm{wt} \%$ catalyst with regards to the oil). The content was stirred using a magnetic stirrer at a rotational speed of $600 \mathrm{rpm}$. A number of experiments were performed at a range of temperatures $\left(20-70{ }^{\circ} \mathrm{C}\right)$. Sampling of the reactor contents was performed at fixed time intervals. The samples were quenched with $0.1 \mathrm{M} \mathrm{HCl}$ in water. The top layer was separated and analysed with ${ }^{1} \mathrm{H}$-NMR (vide infra).

\section{Product analysis}

The biodiesel yield was determined using ${ }^{1} \mathrm{H}-\mathrm{NMR}$ analysis as described by Abduh et al. [9]. The water content of the samples was measured by a Karl Fischer titration using a 702SM Titrino titrator. Acid value of the samples was measured by an acid-base titration with

Table 2 Overview of storage conditions for rubber seeds, RSO and RSO ethyl ester

\begin{tabular}{|c|c|c|}
\hline Material & Storage conditions & Measured property \\
\hline Rubber seeds & $\begin{array}{l}\text { No pre-treatment (NPT), seeds stored in a crate }(50 \times 30 \mathrm{~cm}) \text {, in } \\
\text { layers of } 18 \mathrm{~cm} \text { at } 27^{\circ} \mathrm{C}\end{array}$ & $\begin{array}{l}\text { Humidity, temperature, moisture content, oil content (after Sox- } \\
\text { hlet extraction), acid value (after isolation) }\end{array}$ \\
\hline Rubber seeds & $\begin{array}{l}\text { Pre-treatment (PT) at } 60^{\circ} \mathrm{C} \text { for } 3 \text { days, seeds stored in a crate } \\
\quad(50 \times 30 \mathrm{~cm}) \text {, in layers of } 18 \mathrm{~cm} \text { at } 27^{\circ} \mathrm{C}\end{array}$ & $\begin{array}{l}\text { Humidity, temperature, moisture content, oil content (after Sox- } \\
\text { hlet extraction), acid value (after isolation) }\end{array}$ \\
\hline $\mathrm{RSO}$ & Stored in a closed container at $27^{\circ} \mathrm{C}$ & Acid value \\
\hline RSO ethyl esters & Stored in a closed container at $27^{\circ} \mathrm{C}$ & Acid value \\
\hline
\end{tabular}


phenolphthalein as an indicator. Detailed procedures of the analytical methods for water content and acid value are described elsewhere [9].

The flash point of the samples was measured using a MINIFLASH FLP/H/L in accordance to the methods described in ASTM D 6450 (Standard Test Method for Flash Point by Continuously Closed Cup (CCCFP) Tester). Cloud point (CP) and pour point of the samples were measured according to the methods described in ASTM D 6749 (Standard Test Method for Pour Point of Petroleum Products (Automatic Air Pressure Method) and ASTM D 2500 (Standard Test Method for Cloud Point of Petroleum Products) using a Tanaka Scientific Limited type MPC-102 L.

The density of the oil was measured at $30-100{ }^{\circ} \mathrm{C}$ using a standard picnometer. For this purpose, $10 \mathrm{~mL}$ of a sample was placed in the measuring cell and equilibrated to within $0.1{ }^{\circ} \mathrm{C}$ of the desired temperature. Reported values are the average of duplicate measurements.

The viscosity of the sample was determined using a cone-and-plate viscometer (AR1000-N from TA instrument) with a cone diameter of $40 \mathrm{~mm}$ and a $2^{\circ}$ angle. The measurement was performed at $30-100{ }^{\circ} \mathrm{C}$ with a shear rate of $15 \mathrm{~s}^{-1}$ [18].

\section{Results and discussion}

\section{Rubber seed characteristics}

The experiments were carried out with fresh rubber seeds obtained from Bengkulu, Indonesia. The seeds contain $61 \mathrm{wt} \%$, d.b. kernels, and the remainder being the shells. The initial moisture content of the seeds and kernels as received were approximately 11 and 8 wt\%, w.b., respectively. The dehulled seeds had an average oil content of $49.7 \mathrm{wt} \%$ d.b., as determined by a Soxhlet extraction with $\mathrm{n}$-hexane. This value is within the $40-50 \mathrm{wt} \%$ oil content range as reported in the literature [10].

\section{Effect of storage time of the moisture content of the rubber seeds}

The effect of the storage time on the moisture content of the rubber seeds was determined for rubber seeds with two initial moisture contents (3, and $10.8 \mathrm{wt} \%)$. For the latter, the seeds as received were used (NPT), whereas the seeds with the reduced moisture content were obtained by drying the seeds for 3 days at $60^{\circ} \mathrm{C}(\mathrm{PT})$.

The temperature and relative humidity of the storage room were measured periodically for a 60 day period. The temperature of the storage room was relatively constant $\left(26-28{ }^{\circ} \mathrm{C}\right)$ whereas the relative humidity varied between 60 and $70 \%$ (figure not shown for brevity). Samples of both seed fractions (NPT, PT) were taken periodically and the moisture content was determined, see Fig. 1 for details.
The moisture content of the pre-dried seeds increased slowly in time and after 60 days, equilibrium was not yet attained. Similarly, the moisture content of the nontreated, as received seeds, reduces slowly. Extrapolation suggests that the equilibrium moisture value of the rubber seeds at the prevailing storage conditions is about $9 \mathrm{wt} \%$. This value is in the range reported for jatropha, soybean, sunflower and linseed as shown in Table 3.

\section{Modelling of the moisture content of the rubber seeds versus time}

The moisture content of the rubber seeds as a function of the time (Fig. 1) were modeled using an analytical solution of the diffusion equation for a sphere, see Eq 1 for details [20-22].

$M R=\frac{M-M_{0}}{M_{e}-M_{0}}=1-\frac{6}{\pi^{2}} \sum_{m=1}^{\infty} \frac{1}{m^{2}} e^{\left[\frac{-m^{2} \pi^{2} D_{\text {eff }} t}{r_{0}^{2}}\right]}$

where, $\mathrm{MR}$ is the moisture ratio at time $\mathrm{t}(\mathrm{wt} \%), \mathrm{M}$ is the Moisture content at time $\mathrm{t}(\mathrm{wt} \%), \mathrm{M}_{0}$ is the Initial moisture content (wt\%), $\mathrm{M}_{\mathrm{e}}$ is the Equilibrium moisture content ( $w t \%), \mathrm{D}_{\text {eff }}$ is the Effective diffusion coefficient $\left(\mathrm{m}^{2} / \mathrm{s}\right), \mathrm{r}_{0}$ is the radius $(\mathrm{m}) \mathrm{t}$ is the time $(\mathrm{s})$.

The following assumptions were made:

1. The initial concentration of water is uniform throughout the kernel

2. For time $>0$, the surface and the moisture concentration of the environment are in equilibrium and surface resistance is negligible

3. The moisture content of the environment is constant

4. The diffusion coefficient of water in the kernel is independent of the moisture concentration

5. The rubber seeds are spherical with an average radius of $0.015 \mathrm{~m}$.

The experimental data as given in Fig. 1 for both rubber seed fractions were modelled using Eq. (1), and this allowed determination of the equilibrium moisture content of the seeds and the diffusion coefficients of water in the rubber seeds (at $67 \%$ humidity and $27^{\circ} \mathrm{C}$ ). The results are shown in Table 4 and Fig. 2. The model is in good agreement with the experimental data.

Table 3 Equilibrium moisture values for different oilseeds

\begin{tabular}{lllll}
\hline Oilseed & $\begin{array}{l}\text { Equilibrium } \\
\text { moisture (wt\%) }\end{array}$ & $\begin{array}{l}\text { Storage } \\
\text { temperature }\left({ }^{\circ} \mathbf{C}\right)\end{array}$ & $\begin{array}{l}\text { Relative } \\
\text { humidity (\%) }\end{array}$ & Ref. \\
\hline Jatropha & 8.6 & $25-30$ & $60-70$ & {$[17]$} \\
Soybean & 10.1 & 25 & 65 & {$[19]$} \\
Sunflower & 7.4 & 25 & 65 & {$[19]$} \\
Linseed & 8 & 25 & 65 & {$[19]$} \\
\hline
\end{tabular}




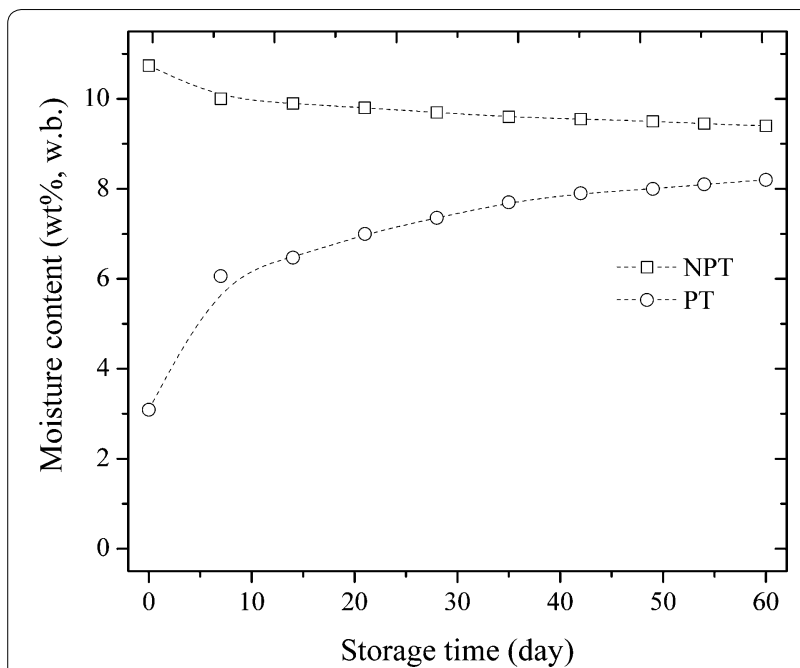

Fig. 1 Effect of storage time on moisture content of the rubber seeds $\left(27^{\circ} \mathrm{C}, 65 \%\right.$ relative humidity

Table 4 Estimated equilibrium moisture content of rubber seeds and effective diffusion coefficient of water in the rubber seeds

\begin{tabular}{lrc}
\hline Parameter & NPT & PT \\
\hline$M_{e}(w t \%)$ & $9.02 \pm 0.09$ & $8.97 \pm 0.08$ \\
$D_{\text {eff }}\left(\mathrm{m}^{2} / \mathrm{s}\right)$ & $0.49 \times 10^{-11} \pm 0.06 \times 10^{-11}$ & $0.78 \times 10^{-11} \pm 0.09 \times 10^{-11}$ \\
\hline
\end{tabular}

Obtained by solving Eq. (1), $27^{\circ} \mathrm{C}, 67 \%$ relative humidity

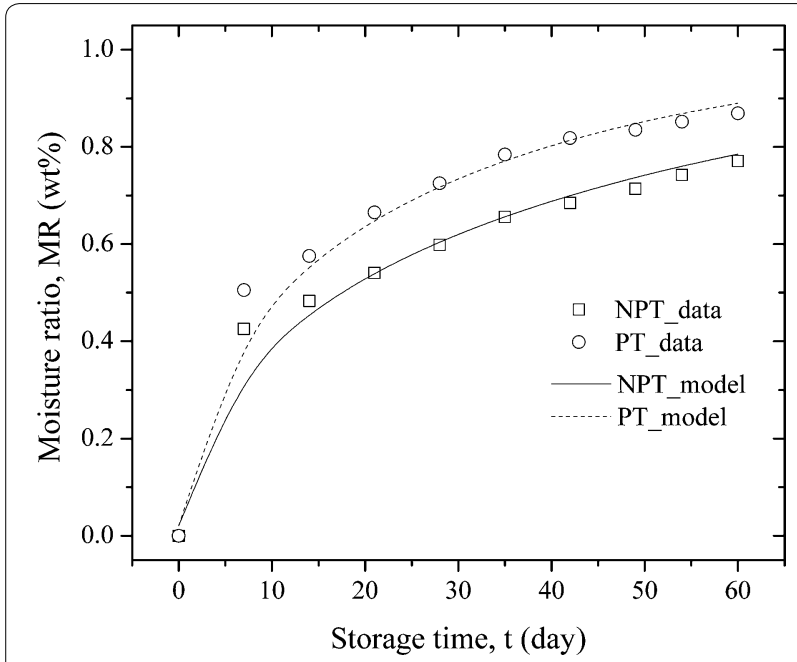

Fig. 2 Experimental and modelled moisture ratio as a function of time for both rubber seed fractions (moisture ratio is defined in Eq. 1)

The estimated equilibrium moisture content $\left(\mathrm{M}_{\mathrm{e}}\right)$ of both rubber seed fractions is identical within the experimental error and approximately $9.0 \mathrm{wt} \%$, in line with other oil seeds (Table 3 ). The modeled diffusion coefficient of water in the rubber seeds as received (NPT) is $0.49 \times 10^{-11}$ $\mathrm{m}^{2} / \mathrm{s}$, which is slightly lower than for the pre-dried samples $\left(\mathrm{PT}, 0.78 \times 10^{-11} \mathrm{~m}^{2} / \mathrm{s}\right)$. These differences are likely due to the occurrence of structural changes upon drying after 3 days at $60{ }^{\circ} \mathrm{C}(\mathrm{PT})$. The diffusion coefficient of water in rubber seeds has not yet been reported. Nevertheless, the modeled diffusion coefficients for NPT and PT are slightly higher than the diffusion coefficients of water in wheat viz. $0.22-0.31 \times 10^{-11} \mathrm{~m}^{2} / \mathrm{s}\left(27-31{ }^{\circ} \mathrm{C}\right)[23]$.

\section{Oil content of rubber seeds and acid value versus storage time}

The oil content of the kernel (dehulled rubber seeds) for both seed fractions (NPT and PT) was determined periodically by taking a certain amounts of seeds and subjecting them to a standardized Soxhlet extraction with n-hexane. The initial oil content of the rubber seeds as received was $49.7 \mathrm{wt} \%$, d.b. After 2 months of storage, the oil content was slightly reduced to $47.8 \mathrm{wt} \%$, d.b. Similar observations were found for the oil content of the predried rubber seeds (48.9 wt\%, d.b. after 2 months versus $49.7 \mathrm{wt} \%$, d.b. initial oil content). As such, the oil content is not largely affected by the time of storage, at least not for a period of 2 months. However, the acid value of the RSO obtained after pressing the seeds increased from 0.8 to $4.2 \mathrm{mg} \mathrm{KOH} / \mathrm{g}$ for NPT and 0.5 to $2.1 \mathrm{mg} \mathrm{KOH} / \mathrm{g}$ for PT upon storage, as shown in Fig. 3.

Thus, it can be concluded that the acid value of the RSO in the stored seeds is a function of the storage time, with longer times leading to higher acid values. In addition, the effect is more pronounced for seeds with a higher initial water content (NPT). As such, a thermal pre-treatment

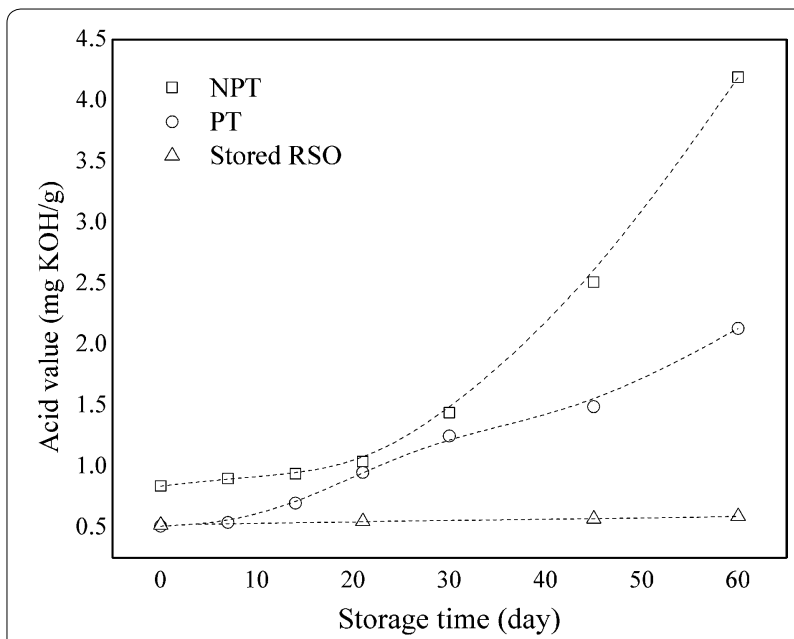

Fig. 3 Effect of storage time on acid value of pressed RSO from stored seeds (NPT and PT) and RSO. The NPT seeds were stored at $27^{\circ} \mathrm{C}$. The PT seeds were initially dried at $60^{\circ} \mathrm{C}$ for 3 days before being stored at $27^{\circ} \mathrm{C}$. RSO was stored in a closed container at $27^{\circ} \mathrm{C}$ 
to reduce the moisture content of seeds before storage has a positive effect on the acid value development versus time of the isolated RSO. These findings suggest that water plays a role in the formation of acid components in the seeds. This may be rationalized by considering that the acid species formed upon storage are likely FFA, formed by the hydrolysis of triglycerides, possibly catalyzed by enzymes present in the seeds. As such, a higher water content in the seeds is expected to favor FFA formation. In addition, the rate of FFA formation in the dried seeds may also be reduced due to a (partly) deactivation of the enzymes by the pre-treatment at $60{ }^{\circ} \mathrm{C}$ for 3 days. The range of acid values of the RSO for the storage experiments is relatively low $(0.5-4.2 \mathrm{mg} / \mathrm{kg} \mathrm{KOH})$ compared to the acid value reported in the literature for RSO, which varies from 2 to $81.6 \mathrm{mg} \mathrm{KOH} / \mathrm{g}$ [15].

Influence of storage time on the acid value of isolated RSO Besides detailed knowledge on the effect of storage time on relevant properties of the rubber seeds (vide supra), it is also of high relevance to get insights in the effect of storage time on the product properties of the RSO. For this purpose, a freshly prepared sample of RSO was prepared. Seeds as received were dehulled and dried in an oven at $60^{\circ} \mathrm{C}$ for 3 days. The kernels were pressed using a laboratory scale hydraulic press $\left(20 \mathrm{MPa}, 35^{\circ} \mathrm{C}, 10 \mathrm{~min}\right)$. Relevant properties of the RSO were determined and shown in Table 5 . The water content, flash point, pour point and cloud point resembles other plant oils reported in the literature [1].

The isolated and characterised RSO was stored at $27^{\circ} \mathrm{C}$ in a closed container and the acidity, a very important product quality indicator, was periodically measured using an acid-base titration. The results are shown in Fig. 3.

The initial acid value was $0.52 \mathrm{mg} \mathrm{KOH} / \mathrm{g}$, and slightly increased to $0.6 \mathrm{mg} \mathrm{KOH} / \mathrm{g}$ upon storage. The trend is different from the acid development curve observed for the rubber seeds, where the acidity increase in time is much more pronounced than for the oil. A likely explanation is

Table 5 Properties of isolated RSO

\begin{tabular}{ll}
\hline Property & RSO \\
\hline Density at $40{ }^{\circ} \mathrm{C}(\mathrm{kg} / \mathrm{l})$ & 0.92 \\
Viscosity at $40^{\circ} \mathrm{C}(\mathrm{mPa} . \mathrm{s})$ & 32.9 \\
Acid value $(\mathrm{mg} \mathrm{KOH} / \mathrm{g})$ & 0.52 \\
Water content $(\mathrm{mg} / \mathrm{kg})$ & 300 \\
Flash point $\left({ }^{\circ} \mathrm{C}\right)$ & 290 \\
Pour point $\left({ }^{\circ} \mathrm{C}\right)$ & -4 \\
Cloud point $\left({ }^{\circ} \mathrm{C}\right)$ & 0 \\
\hline
\end{tabular}

Pressing conditions: $20 \mathrm{MPa}, 35^{\circ} \mathrm{C}$, dried kernels (negligible moisture content) the by far lower water content in the oil (300 ppm) than in the seeds, which will affect the rate of hydrolysis of triglycerides. In addition, enzyme activity is likely negligible in the pressed oil [15]. Zhu et al. observed that the acid value of a crude RSO increased from 18.1 to $31 \mathrm{mg}$ $\mathrm{KOH} / \mathrm{g}$ after 2 months of storage, an increase of $71 \%$ as compared to only $15 \%$ observed in this study. A possible explanation for the differences may be related to differences in initial water content of the samples.

\section{Influence of storage time on the acid value of RSO ethyl esters (RSOEE) \\ Synthesis of RSOEE}

The isolated RSO obtained in the previous section was used as a feed for the synthesis of RSOEE. The esters were prepared by the reaction of the RSO with ethanol using sodium ethoxide as the catalyst in a batch set-up. The low acid value of the $\mathrm{RSO}(0.6 \mathrm{mg} \mathrm{KOH} / \mathrm{g})$ eliminates the necessity of a two steps esterification reaction (initially an acid catalyzed reaction followed by a base catalysed reaction) as proposed in another study [10]. The ethanolysis of RSO was performed at the conditions similar to the ethanolysis of jatropha oil, which was reported previously by our group [9]. The catalyst concentration, ethanol to oil ratio and rotational speed was set at the optimum conditions as determined before for jatropha oil ( $1 \mathrm{wt} \%$ with respect to the oil, 6:1 molar ratio of ethanol to oil, $600 \mathrm{rpm})$. During reaction, samples were taken for analyses, allowing construction of yield versus time profiles. A number of experiments were carried out within a range of temperature $\left(20-70{ }^{\circ} \mathrm{C}\right)$ and the results are presented in Fig. 4.

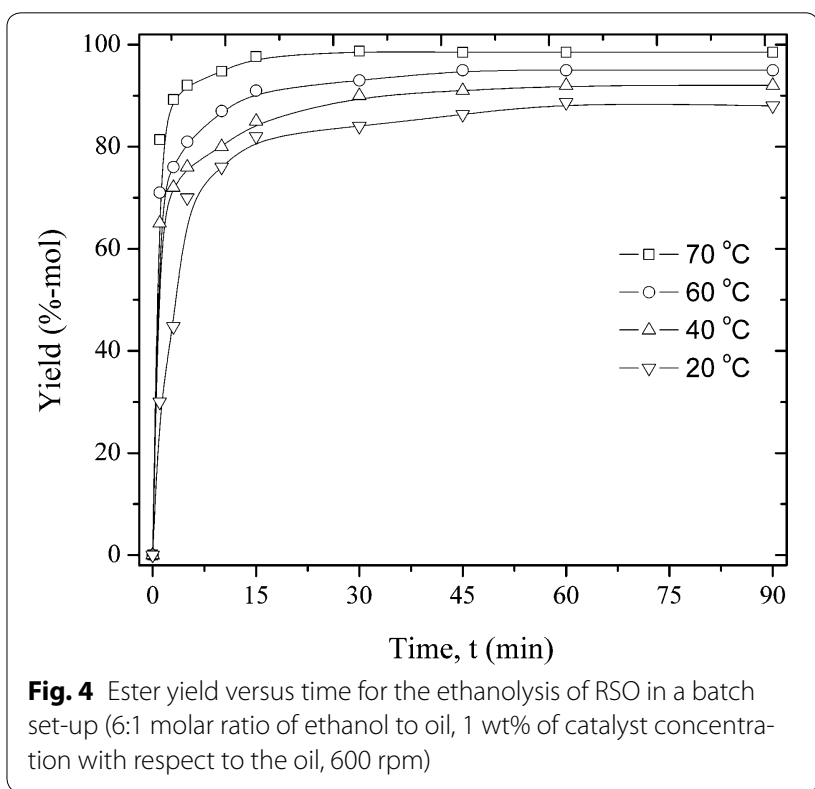


As expected, higher reaction temperatures not only enhance the rate of the esterification reaction but also lead to higher biodiesel yields (Fig. 4). For instance, the ester yield was $98 \mathrm{~mol} \%$ at $70{ }^{\circ} \mathrm{C}$ compared to $88 \mathrm{~mol} \%$ at $20^{\circ} \mathrm{C}$. This observation is in line with previous findings in our group that the maximum (equilibrium) conversion for the synthesis of fatty acid ethyl ester (FAEE) from jatropha oil increased from $93 \mathrm{~mol} \%$ at $50{ }^{\circ} \mathrm{C}$ to $98 \mathrm{~mol} \%$ at $70{ }^{\circ} \mathrm{C}$. This indicates that the equilibrium position of the trans-esterification reactions shifts to the right at higher temperatures, implying that the trans-esterification reaction is slightly endothermic.

The esters yields are higher than reported for the transesterification of RSO using methanol and $\mathrm{NaOH}$ as the catalyst (85\%, 6:1 molar ratio of methanol to oil, $1 \mathrm{wt} \%$ catalyst with respect to the oil, $30^{\circ} \mathrm{C}$ ) [14]. This suggests that the ethanolysis of RSO is faster than methanolysis, supported by other studies [24, 25]. However, literature data are conflicting and others report that the reaction with methanol is faster than with ethanol [26-28]. These contradictory results are likely due to the fact that the reaction is a reactive liquid-liquid system, for which the overall kinetics are not only determined by intrinsic kinetics of the reaction but also by mass transport of reactive components between the L-L interfaces. As such, differences in stirring speed, the type of impeller (simply a magnetic stirring bar or a well-designed impeller) and geometry of the reactor may play an important role. Regarding mass transfer limitations, these are expected to be less of importance for ethanol as the solubility of the plant oil in ethanol is better than in methanol [25].

\section{Relevant product properties of RSOEE}

Relevant properties of the freshly synthesized RSOEE (6:1 molar ratio of ethanol to oil, $1 \mathrm{wt} \%$ of catalyst concentration with respect to the oil, $600 \mathrm{rpm}, 70{ }^{\circ} \mathrm{C}$ ) were determined and are provided in Table 6 . The RSOEE was stored in a closed container at $27{ }^{\circ} \mathrm{C}$ and the acid value was monitored in time (60 days) using an acid-base titration. The acid value upon storage is about constant; from 0.32 to $0.33 \mathrm{mg} \mathrm{KOH} / \mathrm{g}$ after 2 months. This is in agreement with the work by Leung et al. that storage of biodiesel in a closed container at room temperature is less susceptible to degradation compared to exposure to air and storage at $40{ }^{\circ} \mathrm{C}[16]$.

The relevant properties of RSOEE were compared to the biodiesel standard EN 14214 for methyl esters (Table 6). The acid value, water content, Na content, $\mathrm{P}$ content, and flash point are all within specification. The results indicate that the RSOEE produced in this study has the potential be used for commercial applications. Nevertheless, further engine tests are required to determine the performance of RSOEE in combustion engines
Table 6 Properties of rubber seed FAEE

\begin{tabular}{lll}
\hline Property & FAEE & EN 14214 \\
\hline Acid value $(\mathrm{mg} \mathrm{KOH} / \mathrm{g})$ & 0.32 & $0.5 \mathrm{mg} \mathrm{KOH} / \mathrm{g}$ max \\
Water content $(\mathrm{mg} / \mathrm{kg})$ & 400 & $500 \mathrm{mg} / \mathrm{kg}$ max \\
Na content $(\mathrm{mg} / \mathrm{kg})$ & 4 & $5 \mathrm{mg} / \mathrm{kg} \mathrm{max}$ \\
P content $(\mathrm{mg} / \mathrm{kg})$ & 2 & $10 \mathrm{mg} / \mathrm{kg}$ max \\
Flash point $\left({ }^{\circ} \mathrm{C}\right)$ & 171 & $120{ }^{\circ} \mathrm{C}$ min \\
Pour point $\left({ }^{\circ} \mathrm{C}\right)$ & -2 & - \\
Cloud point $\left({ }^{\circ} \mathrm{C}\right)$ & 0 & - \\
\hline
\end{tabular}

and to compare performance with other biodiesels from different plant oils.

\section{Comparison of the acid value versus time profiles for rubber seeds, RSO and RSOEE}

The initial and final acid values after storage ( 2 month, $27^{\circ} \mathrm{C}$ ) for the oil in the rubber seeds, isolated RSO and RSOEE are shown in Table 7 and compared with literature data. The relative increase in the acid value of the oil in the rubber seeds for samples dried at $60{ }^{\circ} \mathrm{C}$ for 3 days (PT procedure, $320 \%$ ) is lower in comparison to the seeds that were not subject to drying at $60{ }^{\circ} \mathrm{C}$ (NPT procedure, $425 \%$ ). This implies the importance of reducing the moisture content of the rubber seeds prior to long term storage. This result is in agreement with a previous study by Abduh et al. that upon storage at higher moisture contents, the triglycerides are likely more susceptible to hydrolysis which results in the formation of FFA with a concomitant increase in the acid value [29]. Previous study done by Ebwele et al. also suggests that the seeds should be dried

Table 7 Acid values for rubber seeds, RSO and RSOEE

\begin{tabular}{|c|c|c|c|}
\hline \multirow[t]{2}{*}{ Material } & \multicolumn{2}{|c|}{$\begin{array}{l}\text { Acid value } \\
\text { (mg KOH/g) }\end{array}$} & \multirow{2}{*}{$\begin{array}{l}\text { Relative increase } \\
\text { (\%) }\end{array}$} \\
\hline & Initial & Final & \\
\hline \multicolumn{4}{|l|}{ Rubber seed } \\
\hline $\mathrm{NPT}^{\mathrm{a}}$ & 0.8 & 4.2 & 425 \\
\hline $\mathrm{PT}^{\mathrm{a}}$ & 0.5 & 2.1 & 320 \\
\hline Entry 1 (Table 1$)^{b}$ & 2 & 8.6 & 330 \\
\hline Entry $2(\text { Table } 1)^{b}$ & 2 & 30.8 & 1440 \\
\hline \multicolumn{4}{|l|}{ Oil } \\
\hline $\mathrm{RSO}^{\mathrm{a}}$ & 0.52 & 0.6 & 15 \\
\hline $\mathrm{RSO}^{\mathrm{b}}$ & 18.1 & 31 & 71 \\
\hline \multicolumn{4}{|l|}{ Biodiesel } \\
\hline RSO ethyl ester ${ }^{a}$ & 0.32 & 0.33 & 3 \\
\hline Rapeseed methyl ester ${ }^{c}$ & 0.15 & 0.22 & 47 \\
\hline
\end{tabular}

a This study, after 2 months storage

b Zhu et al. after 2 months storage [15]

c Leung et al. after 12 months storage [16] 
to a maximum moisture content of $7 \mathrm{wt} \%$ before storage to avoid excessive development of acidity [30].

The results obtained in this study are also in line with the data reported by Zhu et al. for rubber seeds after 2 month of storage in open crates at $27{ }^{\circ} \mathrm{C}$ and $51 \%$ relative humidity (330\%). Worse results were reported by Zhu et al. for rubber seeds stored in piles, which showed a 1400 relative increase in acid content upon storage at $27{ }^{\circ} \mathrm{C}$. This is likely due to poor ventilation leading to a higher pile temperature and Mildew infection [15].

A preliminary techno-economical evaluation on rubber seed drying to reduce the moisture content prior to long term storage was reported by Abduh et al. In this study, a small scale production unit for plant oil and biodiesel from rubber seeds in Palangkaraya, Indonesia is considered. It was assumed that rubber seeds received from a nearby rubber tree plantation have a moisture content of around $10 \mathrm{wt} \%$. The seeds were then assumed to be dried at $60{ }^{\circ} \mathrm{C}$ in an oven to reduce the moisture content to approximately $7 \mathrm{wt} \%$ to improve storage stability. Abduh et al. reported that the production cost of producing rubber seed oil operating at a capacity of 55 ton/y at this location was approximately $€ 0.42 / \mathrm{L}$. Abduh et al. concluded on the basis of this study that RSO may be a competitive renewable resource for stationary electricity generation using a diesel engine [31].

From Table 7, it can be observed that the relative increase in the acidity of the isolated RSO and RSOEE after storage is less than for the oil in the seeds. This result indicates that it is advantageous to store the isolated oil instead of the seeds to avoid excessive built up of acids, and as such have a negative effect on the product specification.

\section{Conclusions and outlook}

The influence of rubber seed storage time on the quality of rubber seed oil has been investigated. Long-term seed storage led to an increase in the acid value of the oils in the rubber seeds. A seed pre-treatment procedure (drying at $60{ }^{\circ} \mathrm{C}$ for 3 days) was shown to have a positive effect and the extent of acid value development in time was lower than for the non-pretreated samples. In addition, the effect of storage time on the product quality and particularly the acid value of isolated rubber seed oil and rubber seed ethyl esters has also been evaluated. Freshly isolated rubber seed oil and rubber seed ethyl esters were shown to have a low acid value of 0.52 and $0.32 \mathrm{mg} \mathrm{KOH} / \mathrm{g}$ respectively. The acid values only slightly increased upon storage in closed containers (2 month, $27^{\circ} \mathrm{C}$ ). As such, it is recommended to store the isolated RSO instead of the rubber seeds to minimize acid formation in the rubber oil. Formation of the latter should be avoided as acids are known to cause major issue during subsequent use (e.g. in stationary engines) and processing (e.g. for biodiesel synthesis) of plant oils.

\section{Authors' contributions}

MYA carried out the experiments and drafted the manuscript. RM and $\mathrm{HJH}$ supervised the entire study. All authors read and approved the final manuscript.

\section{Author details \\ ${ }^{1}$ Department of Chemical Engineering, ENTEG, University of Groningen, Nijenborgh 4, 9747 AG Groningen, The Netherlands. ${ }^{2}$ School of Life Sciences and Technology, Institut Teknologi Bandung, Jalan Ganesha 10, Band- ung 40132, Indonesia.}

\section{Acknowledgements}

The authors thank NWO/WOTRO for a research grant in the framework of the Agriculture beyond Food program.

\section{Competing interests}

The authors declare that they have no competing interests.

Received: 29 December 2015 Accepted: 13 June 2016

Published online: 25 July 2016

\section{References}

1. Balat M (1987) Production of biodiesel from vegetable oils: a survey. Energy Sour Part A 162:156-159

2. Atabani A, Silitonga A, Badruddin IA, Mahlia T, Masjuki H, Mekhilef S (2012) A comprehensive review on biodiesel as an alternative energy resource and its characteristics. Renew Sustain Energy Rev 16:2070-2093

3. Hoekman SK, Broch A, Robbins C, Ceniceros E, Natarajan M (2012) Review of biodiesel composition, properties, and specifications. Renew Sustain Energy Rev 16:143-169

4. Biofuel Production Declines (2014). http://www.worldwatch.org/ biofuel-production-declines

5. Directive 2009/28/EC of the European parliament and of the council (2014) http://ec.europa.eu/energy/renewables/biofuels/doc/biofuels/ com_2012_0595_en.pdf

6. BIODIESEL America's Advanced Biofuel. http://www.biodiesel.org/

7. Gui MM, Lee K, Bhatia S (2008) Feasibility of edible oil vs. non-edible oil vs. waste edible oil as biodiesel feedstock. Energy 33:1646-1653

8. Gupta A, Gupta A (2004) Biodiesel production from Karanja oil. J Sci Ind Res 63:39-47

9. Abduh MY, Vanulden W, Kalpoe V, Vandebovenkamp HH, Manurung R, Heeres HJ (2013) Biodiesel synthesis from Jatropha curcas L. oil and ethanol in a continuous centrifugal contactor separator. Eur J Lipid Sci Technol 115:123-131

10. Ramadhas AS, Jayaraj S, Muraleedharan C (2005) Biodiesel production from high FFA rubber seed oil. Fuel 84:335-340

11. Njoku O, Ononogbu I, Owusu A (1996) An investigation on oil of rubber seed (Hevea brasiliensis). J Rubber Res Inst Sri Lanka 78:52-59

12. Stosic D, Kaykay J (1981) Rubber seeds as animal feed in Liberia. Wld Animal Rev 39:29-39

13. Abdullah B, Salimon J (2009) Physicochemical characteristics of Malaysian rubber (Hevea brasiliensis) seed oil. Eur J Sci Res 31:437-445

14. Ikwuagwu O, Ononogbu I, Njoku O (2000) Production of biodiesel using rubber Hevea brasiliensis (Kunth. Muell.) seed oil. Ind Crops Prod 12:57-62

15. Zhu Y, Xu J, Mortimer PE (2011) The influence of seed and oil storage on the acid levels of rubber seed oil, derived from Hevea brasiliensis grown in Xishuangbanna, China. Energy 36:5403-5408

16. Leung D, Koo B, Guo Y (2006) Degradation of biodiesel under different storage conditions. Bioresour Technol 97:250-256

17. Subroto E, Manurung R, Heeres HJ, Broekhuis AA (2015) Mechanical extraction of oil from Jatropha curcas $L$. kernel. Effect of processing parameters. Ind Crops Prod 97:303-310 
18. Daniel L, Ardiyanti AR, Schuur B, Manurung R, Broekhuis AA, Heeres HJ (2011) Synthesis and properties of highly branched Jatropha curcas L. oil derivatives. Eur J Lipid Sci Technol 113:18-30

19. Pixton S, Warburton S (1971) Moisture content/relative humidity equilibrium of some cereal grains at different temperatures. J Stored Prod Res 6:283-293

20. Delima AB, Delgado J, Santos I, Santos JS, Barbosa E, Silva CJ (2014) GBI Method: a powerful technique to study drying of complex shape solids. In:Transport phenomena and drying of solids and particulate materials. Springer, Berlin, p 25-43

21. Kang S, Delwiche $S$ (2000) Moisture diffusion coefficients of single wheat kernels with assumed simplified geometries. Anal Appl 43:1653-1660

22. Hsu KH (1983) A diffusion model with a concentration-dependent diffusion coefficient for describing water movement in legumes during soaking. J Food Sci 48:618-622

23. Fan L, Chung D, Shellenberger J (1961) Diffusion coefficients of water in wheat kernels. Cereal Chem 38:540-545

24. Fillières R, Benjellounmlayah B, Delmas M (1995) Ethanolysis of rapeseed oil: quantitation of ethyl esters, mono-, di-, and triglycerides and glycerol by high-performance size-exclusion chromatography. J Am Oil Chem Soc 72:427-432

25. Encinar J, Gonzalez J, Rodriguez J, Tejedor A (2002) Biodiesel fuels from vegetable oils: transesterification of Cynara cardunculus L. oils with ethanol. Energy Fuels 16:443-450
26. Rashid U, Ibrahim M, Ali S, Adil M, Hina S, Bukhari I, Yunus R (2012) Comparative study of the methanolysis and ethanolysis of Maize oil using alkaline catalysts. Grasas Aceites 63:35-43

27. Meneghetti SMP, Meneghetti MR, Wolf CR, Silva EC, Lima GE, Silva LL, Serra TM, Cauduro F, De Oliveira LG (2006) Biodiesel from castor oil: a comparison of ethanolysis versus methanolysis. Energy Fuels 20:2262-2265

28. Vieitez I, Da Silva C, Alckmin I, Borges GR, Corazza FC, Oliveira JV, Grompone MA, Jachmanián I (2010) Continuous catalyst-free methanolysis and ethanolysis of soybean oil under supercritical alcohol/water mixtures. Renew Energy 35:1976-1981

29. Abduh MY, Rasrendra CB, Subroto E, Manurung R, Heeres HJ (2016) Experimental evaluation and modelling of solvent assisted hydraulic pressing of dehulled rubber seeds. submitted to Ind. Crops Prod

30. Ebwele R, lyayi A, Hymore F (2010) Considerations of the extraction process and potential technical applications of Nigerian rubber seed oil. Int J Phys Sci 5:826-831

31. Abduh MY, Manurung R, Heeres HJ (2016) Techno-economic analysis for small scale production of plant oil and biodiesel from rubber seeds in Palangkaraya, Indonesia. MATEC Web of Conferences

\section{Submit your manuscript to a SpringerOpen ${ }^{\circ}$ journal and benefit from:}

- Convenient online submission

- Rigorous peer review

- Immediate publication on acceptance

- Open access: articles freely available online

- High visibility within the field

- Retaining the copyright to your article 